\title{
Experimental Investigation of Air-to-Air Counter Flow Heat Pipe Heat Exchanger for Heat Recovery System
}

\author{
Manisha Rathod \\ Mechanical Engineering Department, Trinity College of Engineering and Research, Pune, India
}

\begin{abstract}
This paper deals with the waste heat recovery using heat pipe heat exchanger. Heat pipe is a device which carries the heat from high temperature region \& ejects it to the cold or low temperature region. The advantage of using a heat pipe over other conventional methods is that large quantities of heat can be transported through a small crosssectional area over a considerable distance with no additional power input to the system. The heat pipe heat exchangers are used in heat recovery applications to cool the incoming fresh air. Two streams of fresh and return air are connected with heat pipe heat exchanger to investigate the thermal performance and effectiveness of heat recovery system. The aim of this project work is to investigate the thermal performance and effectiveness of heat pipe heat exchanger for heat recovery applications by measuring the temperature difference of warm and cold air through the evaporator and condenser side. The hot-air temperature increased from 60 to $90^{\circ} \mathrm{C}$; the heat-transfer rate increased slightly. The mass flow rate of hot air increased from $0.30997,0.4643,0.4889,0.508 \mathrm{~kg} / \mathrm{s}$ led to a slight increase in effectiveness. As the hot-air temperature increases from 60 to $90^{\circ} \mathrm{C}$, the effectiveness slightly increased.
\end{abstract}

Keywords: Heat pipe; Heat pipe Heat exchanger; Heat recovery.

\section{INTRODUCTION}

In the light of an ever increasing demand for energy, the need for energy savings has become an important economic consideration. One means of saving energy is to recover a portion of the energy in a warm waste stream and then to use the recovered energy to preheat another colder stream. Heat pipe heat exchanger for heat recovery equipment are aimed for recovering sensible heat and they are recommended for systems in which inlet and return air should not be mixed such as surgery rooms in hospitals and chemical and biological laboratories. The advantage of using heat pipes over conventional methods is that large quantities of heat can be transported through a small crosssectional area over a considerable distance with no additional power input to the system, (except for the fans to drive the airstreams) together with simplicity of design and ease of manufacture, [1]; less pressure drop of fluid; advanced maintainability; high reliability; simpler structure and smaller volume. Gravity assisted heat pipe, for its special characters of without wicks, has found numerous applications in heat recovery systems in terrene. HPHXs are suitable for energy recovery in AC systems in tropical areas where the inlet fresh air at high temperature could be pre-cooled before it reaches the cooling coil. A HPHX is a heat exchanger consisting of externally finned tubes filled with a proper refrigerant (i.e. working fluid). There are two heat transfer sections in HPHXs, i.e. the evaporator and the condenser sections for the heat exchange between the two air streams.[2,3]

Yang et al.[4] have studied the feasibility of using heat pipe heat exchangers for heating applying automotive exhaust gas. Noieet at. [5] designed and constructed heat pipe heat exchanger for heat recovery in hospital and laboratories, where the air must be changed up to 40 times per hour, with the characteristic design and heat transfer limitations of single heat pipes for three working fluids and three types of wick have been investigated. El-Baky and Mohamed [6] used heat pipe heat exchanger to recover heat in air conditioning applications to cool the incoming fresh air. Martinez et al. [7] designed a mixed air-energy recovery system, consisting of two heat pipes and indirect evaporative recuperators. The experimental set-up used is described and the proposed energy recovery system is characterized.S. Rittidech et al. [8] studied the CEOHP air-preheater consisted of two main parts, i.e. the rectangular house casing and the CEOHP. The house casing was designed to be suitable for the CEOHP. The inside house casing divided the CEOHP into three parts, i.e. the evaporator, the adiabatic section and condenser section. Meena [9] used a CLOHP/CV air-preheater for recovering the waste heat from the drying cycle to reduce the relative humidity and achieve energy thrift. Ahmadzadehtalatapeh and Yau [10] studied the effect of heat pipe heat exchangers on the existing air conditioning system of a hospital ward located ina tropical region.It was found that by applying the new design, a considerable amount of energy and power could be saved.Yau[11] developed an 8-row thermosyphon-based heat pipe heat exchanger (HPHX) for tropical building HVAC systemsfor dehumidification enhancement.Hagens et al.[12] done measurements and predictions of a heat pipe heat exchanger with two filling ratios of R134a, varying air flow rate and input temperature, and suggested that a 
heat pipe equipped heat exchanger is a good alternative for air-air exchangers in process conditions when air-water cooling is impossible, typically in warmer countries. Laubscher and Dobson [13] developed a novel heat pipe heat exchanger which circumvents the need for an intermediate coolant loop, using Dowtherm-A as working fluid.

\section{EXPERIMENTAL SET UP}

In order to study thermal performance of the heat pipe heat exchanger, a test rig was constructed. The schematic diagram of the test rig is shown in fig 2.1 and actual test rig is shown in fig 2.2

The test rig consists of

A heat pipe heat exchanger

A centrifugal blower

Electrical heaters (with total capacity of $20 \mathrm{~kW}$ )

Thermocouples

Temperature monitor and two rectangular air ducts; one for the hot air and the other for cold air.

The flow rates of hot and cold air were determined by measuring the velocity of air using a digital flow meter.

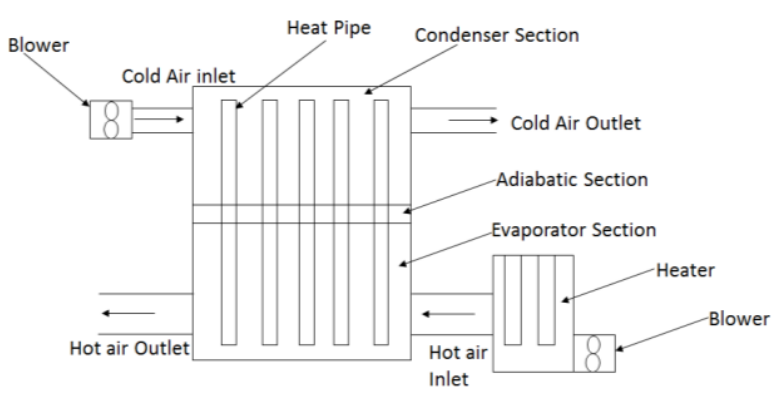

Fig. 2.1: Experimental set up

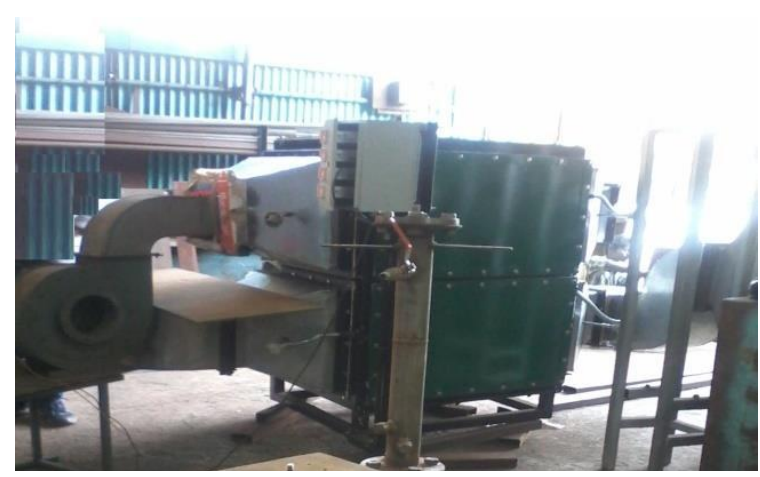

Fig 2.2: Actual experimental set up

The physical parameter of HPHE are given in table 2.1

Table 2.1 physical parameter of heat pipe heat exchanger

\begin{tabular}{|c|l|l|}
\hline Sr. no & Description & Specifications \\
\hline $\mathbf{1}$ & $\begin{array}{l}\text { Physical dimensions of } \\
\text { the heat exchanger }\end{array}$ & $\begin{array}{l}770 \mathrm{~mm} \text { (length) } \\
\text { 420mm(width) } \\
900 \mathrm{~mm} \text { (height) }\end{array}$ \\
\hline $\mathbf{2}$ & Physical dimensions of & $\mathrm{D}_{\mathrm{o}}=25.4 \mathrm{~mm}, \mathrm{D}_{\mathrm{i}}$ \\
\hline
\end{tabular}

\begin{tabular}{|c|c|c|}
\hline & each heat pipe & $\begin{array}{l}=22.4 \mathrm{~mm}, \mathrm{~L}_{\text {tubes }} \\
=0.6 \mathrm{~m}\end{array}$ \\
\hline 3 & $\begin{array}{l}\text { Type and dimensions } \\
\text { of fins Aluminum plate } \\
\text { fin, }\end{array}$ & $\begin{array}{l}\text { thickness }=0.4 \\
\mathrm{~mm}\end{array}$ \\
\hline 4 & $\begin{array}{l}\text { Heat pipe arrangement } \\
\text { Staggered, }\end{array}$ & $\begin{array}{l}\mathrm{S}_{\mathrm{L}}=77 \mathrm{~mm}, \mathrm{~S}_{\mathrm{T}}= \\
90 \mathrm{~mm}\end{array}$ \\
\hline 5 & Number of rows & $\mathrm{N}_{\mathrm{L}}=10, \mathrm{~N}_{\mathrm{T}}=4$ \\
\hline 6 & $\begin{array}{l}\text { Total number of the } \\
\text { heat pipes }\end{array}$ & $\mathrm{N}=40$ \\
\hline \multirow[t]{2}{*}{7} & $\begin{array}{l}\text { Heat pipe } \\
\text { material/working fluid }\end{array}$ & SS/water \\
\hline & $\begin{array}{l}\text { Design/Construction } \\
\text { Details }\end{array}$ & cold side hot side \\
\hline 8 & Type of Fluid & $\begin{array}{l}\text { Air } \\
\text { Air }\end{array}$ \\
\hline 9 & $\begin{array}{l}\text { Design inlet } \\
\text { temperature }\end{array}$ & $\begin{array}{l}\text { Atmospheric 80- } \\
100^{\circ} \mathrm{C}\end{array}$ \\
\hline 10 & Design air flow rate & $\begin{array}{l}0.1-0.6 \quad 0.1- \\
0.6 \mathrm{~kg} / \mathrm{sec}\end{array}$ \\
\hline 11 & Type of Fins on HP & Circular \\
\hline 12 & $\begin{array}{l}\text { Method of fin } \\
\text { attachment }\end{array}$ & Shrink fit \\
\hline 13 & Fin Density & $5 \mathrm{fpi}$ \\
\hline 14 & $\begin{array}{l}\text { No. of HP rows along } \\
\text { the flow }\end{array}$ & 10 \\
\hline 15 & $\begin{array}{l}\text { No. of HP rows across } \\
\text { the flow }\end{array}$ & 4 \\
\hline 16 & $\begin{array}{l}\text { Total no. of HP with } \\
\text { water as working fluid }\end{array}$ & 40 \\
\hline 17 & $\begin{array}{l}\text { Type and size of inlet } \\
\text { and outlet of Heat } \\
\text { Exchanger }\end{array}$ & Rectangular \\
\hline 18 & HP tube Material & SS-304 \\
\hline 19 & Fin material & SS-304 \\
\hline 20 & Support structure & Carbon steel \\
\hline 21 & Casing material & $\begin{array}{l}\text { Carbon } \\
\text { steel,IS2062 }\end{array}$ \\
\hline
\end{tabular}

\section{III.EXPERIMENTAL RESULTS AND DISCUSSIONS}

A series of tests was performed in order to investigate the characteristics of the heat pipe heat exchanger. The readings were taken by varying mass flow rate of hot air from $8.5 \mathrm{~m} / \mathrm{s}$ to $20 \mathrm{~m} / \mathrm{s}$ and the air velocity of cold air was $19 \mathrm{~m} / \mathrm{s}$ and maintained constant throughout the experimentation. The readings were taken by varying hot air temperatures from $65^{\circ} \mathrm{C}$ to $90^{\circ} \mathrm{C}$, the results are discussed in this section.

Fig 3.1 shows the effect of heat input on heat transfer rate to condenser. In this figure $\mathrm{X}$ axis represent the heat input and $\mathrm{Y}$ axis represents the heat transfer to condenser. From fig the increase in heat input to the evaporator section causes the increase in heat transfer to the condenser section. The heat transfer rate is maximumfor the maximum heat input. For the $5.1 \mathrm{~kW}$ of heat input heat transfer to the condenser section is $3.51 \mathrm{~kW}$. 


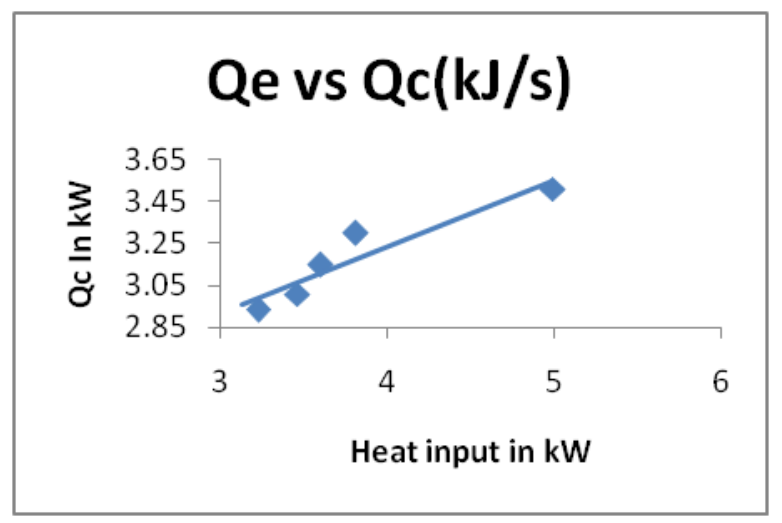

Fig 3.1: Effect of heat input on heat transfer rate

Figure 3.2 shows the effect of evaporator heat input on effectiveness for different mass flow rate. The heat input is varied by varying the hot air inlet temperature. As the heat input to the evaporator increases the effectiveness of the heat exchanger increases.

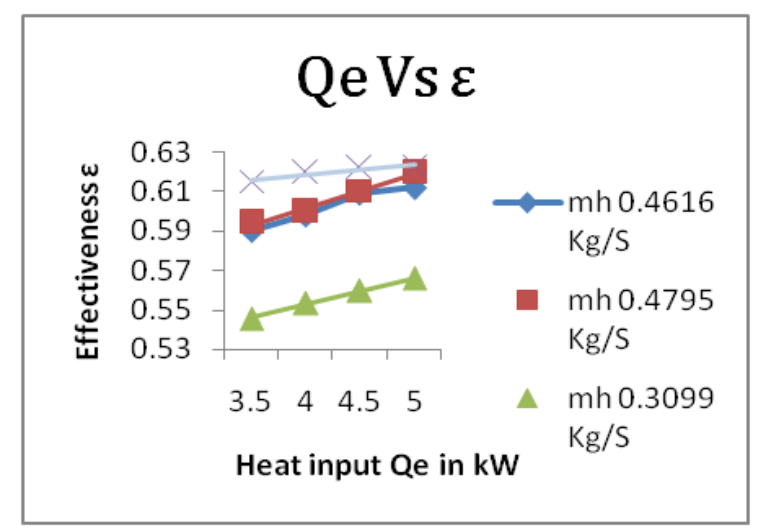

Fig 3.2: Effect of heat input on effectiveness

The effectiveness is maximum for the maximum heat input and the maximum mass flow rate. As the effectivness is depend on the heat input and the heat transfer to condenser. $Q=m C_{P}\left(T_{i}-T_{o}\right)$ this equation shows that heat transfer is depend on the mass flow rate therefore when mass flow rate increases heat transfer rate increases and it causes increase in effectiveness. We got maximum effectivness 0.62 at maximum mass flow rate of $0.5077 \mathrm{~kg} / \mathrm{S}$ and at heat input of $5.103 \mathrm{~kW}$

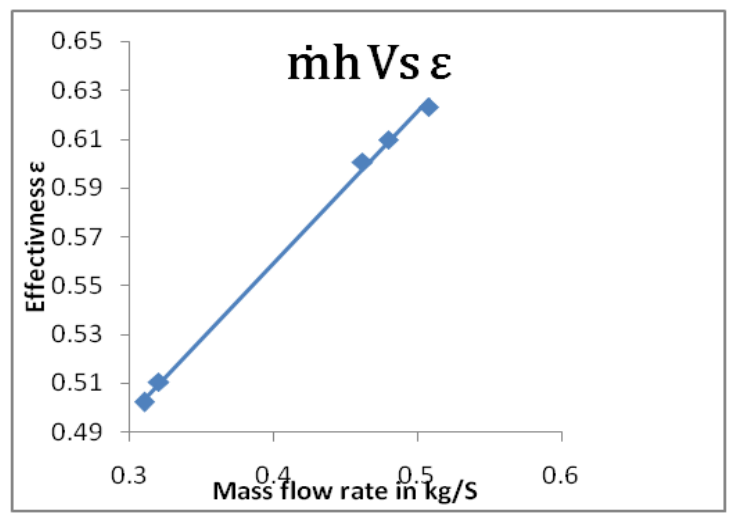

Fig 3.3 Effect of mass flow rate on effectiveness
Figure 3.3 shows the effect of mass flow rate on effectiveness. In this figure $\mathrm{X}$ axis represents the mass flow rate and the $\mathrm{Y}$ axis represents the effectiveness of heat exchanger. The effectiveness of heat exchanger increases with increase in mass flow rate.

When the mass flow rate increases the heat input is increased. And the effectiveness is depends on the heat input and heat transferred to condenser. With increase in mass flow rate the heat input is increased and it causes to increase in effectiveness of the heat exchanger. The maximum effectiveness is 0.62 at minimum mass flow rate $0.5077 \mathrm{Kg} / \mathrm{S}$.

The effect of change in Reynolds number on heat transfer coefficient at evaporator side is shown in figure 3.4.

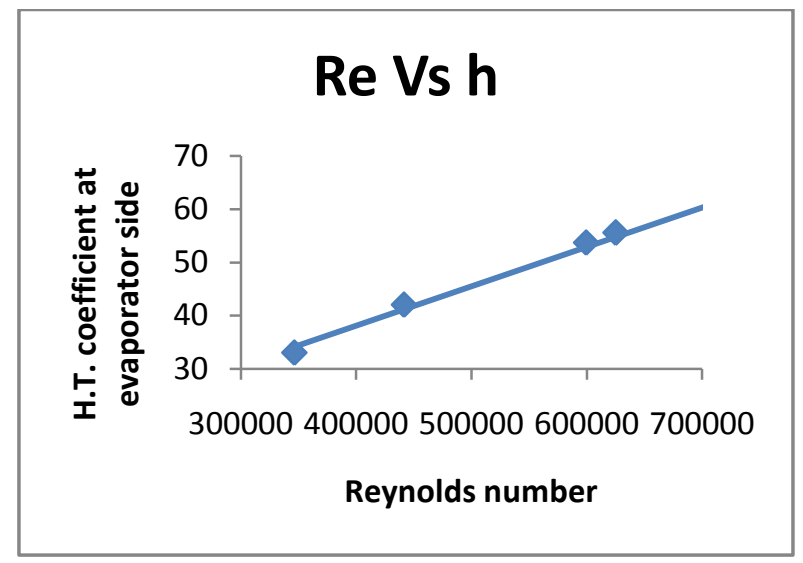

Fig 3.4 Effect of Reynolds no on heat transfer coefficient at evaporator side

As Reynolds number increases the heat transfer coefficient increases. Nusselt number is a function of Reynolds number and Prandlt number.

For turbulent flow

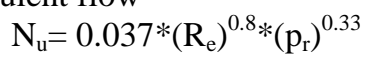

For laminar flow,

$$
\mathrm{N}_{\mathrm{u}}=0.664 *\left(\mathrm{R}_{\mathrm{e}}\right)^{0.5} *\left(\mathrm{p}_{\mathrm{r}}\right)^{0.33}
$$

These equation shows as Reynolds number increases the Nusselt number increases. But Nusselt number is a function of heat transfer coefficient.

$$
\mathrm{N}_{\mathrm{u}}=\frac{h L}{K}
$$

Therefore from this equation when Nusselt number increases the heat transfer coefficient increases. The maximum heat transfer coefficient obtained at maximum Reynolds number. $59.84 \mathrm{~W} / \mathrm{mK}$ heat transfer coefficient obtained at the Reynolds number $6.9 * 10^{5}$.

The effect of change in Reynolds number on Nusselt number is shown in figure 3.5. In this figure $\mathrm{X}$ axis shows the Reynolds number and $\mathrm{Y}$ axis shows the Nusselt number. 


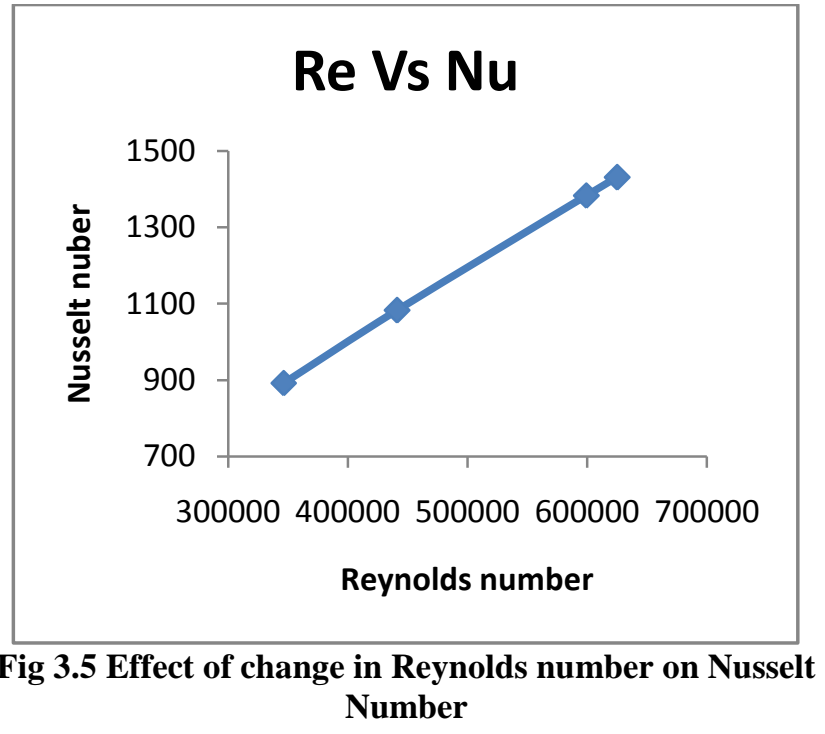

As Reynolds number increases the heat transfer coefficient increases. Nusselt number is a function of Reynolds number and Prandlt number.

For turbulent flow

For laminar flow,

$$
\mathrm{N}_{\mathrm{u}}=0.037 *\left(\mathrm{R}_{\mathrm{e}}\right)^{0.8 *}\left(\mathrm{p}_{\mathrm{r}}\right)^{0.33}
$$

$$
\mathrm{N}_{\mathrm{u}}=0.664 *\left(\mathrm{R}_{\mathrm{e}}\right)^{0.5 *}\left(\mathrm{p}_{\mathrm{r}}\right)^{0.33}
$$

These equation shows as Reynolds number increases the Nusselt number increases. The 1501 Nusselt number obtained at $6.9 * 10^{5}$ Reynolds number.

\section{CONCLUSIONS}

In the present work, Heat pipe heat exchanger with 40 heat pipe is used to investigate the thermal performance of heat pipe heat exchanger. In this variation of heat transfer to the condenser is investigated with the varying heat input. Effect of heat input and mass flow rate on the effectiveness for different mass flow rate is also studied. Variation of Nusselt number and heat transfer coefficient with the varying Reynolds number is reported.

The main conclusions are summarized as follows:

i. The increase in heat input to the evaporator section causes the increase in heat transfer to the condenser section. The heat transfer rate is maximum for the maximum heat input. For the $5.1 \mathrm{~kW}$ of heat input heat transfer to the condenser section is $3.51 \mathrm{~kW}$.

ii. As the heat input to the evaporator increases the effectiveness of the heat exchanger increases. We got maximum effectivness 0.62 at maximum mass flow rate of $0.5077 \mathrm{~kg} / \mathrm{S}$ and at heat input of $5.103 \mathrm{~kW}$.

iii. The effectiveness of heat exchanger increases with increase in mass flow rate. The maximum effectiveness is 0.62 at minimum mass flow rate $0.5077 \mathrm{Kg} / \mathrm{S}$.

iv. Increase in Reynolds number increases the heat transfer coefficient increases. $59.84 \mathrm{~W} / \mathrm{mK}$ heat transfer coefficient obtained at the Reynolds number $6.9 * 10^{5}$ v. Increase in Reynolds number increases the heat transfer coefficient increases. The 1501 Nusselt number obtained at $6.9 * 10^{5}$ Reynolds number.

\section{REFERENCES}

[1] Jay M. Ochterbeck, Heat Pipes, chapter 16, 1181-1184.

[2] David Reav, Peter Kew, Heat pipes, 5 th edition, Pergamon Press, Oxford, UK, (2006).

[3] Faghri A., Heat pipe science and technology, Taylor and Francis Washington DC, USA, (1995).

[4] Cengel, Heat and mass transfer, McGraw hill education, (2002)

[5] Yang F, Yuan X, Lin G. Waste heat recovery using heat pipe heat exchanger for heating automobile using exhaust gas. Applied Thermal Engineering 2003; 23:367-72.

[6] Noie-Baghban S, Majideian G. Waste heat recovery using heat pipe heat exchanger (HPHE) for surgery rooms in hospitals. Applied Thermal Engineering 2000; 20:1271-82.

[7] Abd El-Baky MA, Mohamed MM. Heat pipe heat exchanger for heat recovery in airnconditioning. Applied Thermal Engineering 2007; 27:795-801.

[8] Martinez FJR, Plasencia MAA, Gomez EV, Diez FV, Martin RH. Design and experimental study of mixed energy recovery system, heat pipe and indirect evaporative equipment for air conditioning. Energy and Buildings 2003; 35:1021-30.

[9] Rittidech S, Dangeton W, Soponronnarit S. Closed-ended oscillating heat pipe (CEOHP) air-preheater for energy thrift in a dryer. Applied Energy 2005; 81:198-208.

[10] Meena P, Rittidech S, Poomsa-ad N. Closed-loop oscillating heatpipe with check valves (CLOHP/CVs) air-preheater for reducing relative humidity in drying systems. Applied Energy 2007; 84:36373.

[11] M. Ahmadzadehtalatapeh, Y.H. Yau, The application of heat pipe heat exchangers to improve the air quality and reduce the energy consumption of the air conditioning system in a hospital ward-A full year model simulation, Energy and Buildings 43 (2011) 23442355.

[12] Yat H. Yau, Application of a heat pipe heat exchanger to dehumidification enhancement in a HVAC system for tropical climates - a baseline performance characteristics study, International Journal of Thermal Sciences 46 (2007) 164-171.

[13] H. Hagens, F.L.A. Ganzevles, C.W.M. van der Geld, M.H.M. Grooten, Air heat exchangers with long heat pipes: Experiments and predictions, Applied Thermal Engineering 27 (2007) 24262434. 